\title{
Volumetric and viscometric studies on dodecyltrimethylammonium bromide in aqueous and in aqueous amino acid solutions in premicellar region
}

\author{
M. Farhad Hossain - Tapan Kumar Biswas • \\ M. N. Islam • M. Entazul Huque
}

Received: 9 September 2009/Accepted: 12 September 2010/Published online: 14 October 2010

(C) The Author(s) 2010. This article is published with open access at Springerlink.com

\begin{abstract}
The densities and viscosities of dodecyltrimethylammonium bromide (DTAB), glycine, and racalanine in water and DTAB in glycine/alanine aqueous solutions have been determined at 288.15, 296.15, 304.15, 312.15 , and $320.15 \mathrm{~K}$. The apparent molar volumes $\left(\varphi_{\mathrm{v}}\right)$ were obtained from these density data. The limiting apparent molar volumes $\left(\varphi_{\mathrm{v}}^{0}\right)$ and experimental slopes $\left(S_{\mathrm{v}}\right)$ were derived from the Masson equation and interpreted in terms of solute-solute and solute-solvent interactions. The sign of $\left[\delta^{2}\left(\varphi_{\mathrm{v}}^{0}\right) / \delta T^{2}\right]_{\mathrm{p}}$, which corresponds to structuremaking or structure-breaking properties of solutes, was determined. The viscosity coefficients $A, B$, and $D$ were obtained from viscosity data on the basis of the Jones-Dole equation. Glycine/alanine in aqueous solutions exhibit structure-breaking behavior. In premicellar region, DTAB in aqueous solutions exhibits structure-breaking behavior, and DTAB in aqueous glycine/alanine solutions exhibits structure-making behavior. The free energy, enthalpy, and entropy of activation were calculated using the Nightingale and Benck, and Eyring equations. The values of $\left(\Delta \mu_{1}^{\#}-\right.$ $\left.\Delta \mu_{0}^{\#}\right)$ for solutions were calculated. The effects of solutes on the structure of water were interpreted in terms of viscosities and the thermodynamic parameters.
\end{abstract}

M. F. Hossain · T. K. Biswas · M. N. Islam · M. E. Huque ( $\square)$

Department of Chemistry, University of Rajshahi,

Rajshahi 6205, Bangladesh

e-mail: emhuque@yahoo.com

T. K. Biswas

e-mail: tapankb@ru.ac.bd
Keywords Apparent molar volume .

Partial molar volume - Viscosity coefficient .

Activation parameter

\section{Introduction}

Volumetric, viscometric, and other thermodynamic data provide valuable information regarding solute-solvent, solute-solute, and solvent-solvent interactions [1, 2]. Although volumetric, viscometric, and related thermodynamic parameter values in binary systems are abundantly available, data on ternary systems are limited. Physicochemical studies on aqueous ternary systems are gaining importance, because sometimes it is difficult to arrive at a definite conclusion regarding structure and properties of solutions from studies on binary systems alone. DTABwater and amino acid-water mixtures are of great importance in protein stability and denaturation phenomena [3-10].

The effect of DTAB and amino acids on protein structure is now recognized to be more complex than simply disruption of hydrogen bonds and, in particular, causes the breaking of hydrophobic bonds [11-13]. The effects of added DTAB and amino acids upon the properties of water are continuously investigated in order to understand the mechanism of protein stability and denaturation by DTAB and amino acids. These effects are reported to be intimately connected with the local liquid structure [14, 15]. In this study we made an attempt to: (a) interpret the apparent and partial molar volume and the viscosity coefficients $A, B$, and $D$ in terms of ion-ion, solute-solvent, and solutesolute interactions; (b) study the effect of DTAB on these interactions; (c) investigate the structure-making/breaking properties of the amino acids; and (d) discuss the species 
involved in viscous flow by their characteristic activation parameters $\Delta G^{\#}, \Delta S^{\#}, \Delta H^{\#}$, and $\left(\Delta \mu_{1}^{\#}-\Delta \mu_{0}^{\#}\right)$ in the premicellar region of DTAB.

\section{Results and discussion}

Volumetric properties of glycine, alanine, and DTAB in aqueous solutions and DTAB in aqueous amino acid solutions were determined at 288.15, 296.15, 304.15, 312.15 , and $320.15 \mathrm{~K}$. The apparent molar volume $\left(\varphi_{\mathrm{v}}\right)$ and partial molar volume of binary and ternary solutions are shown in Tables 1, 2, and 3 (alanine solution data are not shown because they are very similar to glycine data). The apparent molar volumes depend on solute concentration as well as on temperature [16]. In aqueous glycine solutions, the apparent molar volumes show linear variation with concentration [17] (Fig. 1). Similar behavior was also seen in case of temperature rise. Comparatively higher apparent molar volumes $\left(\varphi_{\mathrm{v}}\right)$ for DTAB in aqueous amino acid solutions are more progressively structure than in the aqueous system alone.

The variation of apparent molar volume of DTAB in aqueous and in aqueous amino acid solutions in the lowconcentration region $\left(\varphi_{\mathrm{v}}-\sqrt{\mathrm{m}}\right.$ plots $)$ shows a sudden change in the $\varphi_{\mathrm{v}}$ value at a particular molality (Figs. 2, 3). The apparent molar volume of DTAB in aqueous and in aqueous amino acid solutions may have two components, viz. the true size of the molecule and the free space between the molecules. In premicellar region, the

Table 1 Concentration dependence of apparent molar volumes and partial molar volumes for glycine in aqueous solutions at 288.15, 296.15, $304.15,312.15$, and $320.15 \mathrm{~K}$

\begin{tabular}{|c|c|c|c|c|c|c|c|c|c|c|}
\hline \multirow{2}{*}{$\begin{array}{l}\text { Conc. } \\
\mathrm{m}\left(\mathrm{mol} \mathrm{kg}{ }^{-1}\right)\end{array}$} & \multicolumn{5}{|c|}{ Apparent molar volume $\varphi_{\mathrm{v}}\left(\mathrm{cm}^{3} \mathrm{~mol}^{-1}\right)$} & \multicolumn{5}{|c|}{ Partial molar volume $\overline{V_{2}}\left(\mathrm{~cm}^{3} \mathrm{~mol}^{-1}\right)$} \\
\hline & $288.15 \mathrm{~K}$ & $296.15 \mathrm{~K}$ & $304.15 \mathrm{~K}$ & $312.15 \mathrm{~K}$ & $320.15 \mathrm{~K}$ & $288.15 \mathrm{~K}$ & $296.15 \mathrm{~K}$ & $304.15 \mathrm{~K}$ & $312.15 \mathrm{~K}$ & $320.15 \mathrm{~K}$ \\
\hline 0.0499 & 41.51 & 42.29 & 43.14 & 43.39 & 44.00 & 41.56 & 42.36 & 43.48 & 43.48 & 44.06 \\
\hline 0.1003 & 41.49 & 42.62 & 43.23 & 43.51 & 44.04 & 41.58 & 42.78 & 43.68 & 43.68 & 44.15 \\
\hline 0.1501 & 41.90 & 42.88 & 43.35 & 43.57 & 44.21 & 42.04 & 43.10 & 43.83 & 43.83 & 44.37 \\
\hline 0.1997 & 42.20 & 43.05 & 43.54 & 43.77 & 44.32 & 42.38 & 43.35 & 44.11 & 44.11 & 44.54 \\
\hline 0.2504 & 42.17 & 43.24 & 43.68 & 43.98 & 44.47 & 42.40 & 43.62 & 44.40 & 44.40 & 44.74 \\
\hline 0.2998 & 42.19 & 43.29 & 43.81 & 44.02 & 44.42 & 42.47 & 43.74 & 44.53 & 44.53 & 44.75 \\
\hline 0.3486 & 42.07 & 43.23 & 43.80 & 44.00 & 44.43 & 42.40 & 43.76 & 44.59 & 44.59 & 44.80 \\
\hline 0.3985 & 42.18 & 43.34 & 43.89 & 44.11 & 44.52 & 42.55 & 43.94 & 44.79 & 44.79 & 44.95 \\
\hline 0.4498 & 42.00 & 43.46 & 43.99 & 44.22 & 44.60 & 42.42 & 44.14 & 44.99 & 44.99 & 45.09 \\
\hline 0.4998 & 42.03 & 43.42 & 43.95 & 44.19 & 44.56 & 42.50 & 44.17 & 45.04 & 45.04 & 45.10 \\
\hline 0.5488 & 42.07 & 43.61 & 44.13 & 44.38 & 44.74 & 42.58 & 44.44 & 45.31 & 45.31 & 45.33 \\
\hline
\end{tabular}

Table 2 Concentration dependence of apparent molar volumes and partial molar volumes for DTAB in aqueous solutions at $288.15,296.15$, $304.15,312.15$, and $320.15 \mathrm{~K}$

\begin{tabular}{|c|c|c|c|c|c|c|c|c|c|c|}
\hline \multirow{2}{*}{$\begin{array}{l}\text { Conc. } \\
\mathrm{m}\left(\mathrm{mol} \mathrm{kg}^{-1}\right)\end{array}$} & \multicolumn{5}{|c|}{ Apparent molar volume $\varphi_{\mathrm{v}}\left(\mathrm{cm}^{3} \mathrm{~mol}^{-1}\right)$} & \multicolumn{5}{|c|}{ Partial molar volume $\overline{V_{2}}\left(\mathrm{~cm}^{3} \mathrm{~mol}^{-1}\right)$} \\
\hline & $288.15 \mathrm{~K}$ & $296.15 \mathrm{~K}$ & $304.15 \mathrm{~K}$ & $312.15 \mathrm{~K}$ & $320.15 \mathrm{~K}$ & $288.15 \mathrm{~K}$ & $296.15 \mathrm{~K}$ & $304.15 \mathrm{~K}$ & $312.15 \mathrm{~K}$ & $320.15 \mathrm{~K}$ \\
\hline 0.0005 & 274.56 & 274.93 & 281.52 & 280.19 & 278.96 & 275.62 & 276.32 & 282.89 & 282.19 & 281.78 \\
\hline 0.0010 & 283.57 & 285.98 & 288.58 & 290.34 & 290.20 & 284.99 & 287.70 & 290.17 & 292.50 & 293.15 \\
\hline 0.0015 & 278.55 & 280.28 & 284.21 & 285.60 & 286.45 & 280.29 & 282.39 & 286.14 & 288.25 & 290.02 \\
\hline 0.0020 & 276.55 & 281.45 & 284.03 & 286.78 & 288.15 & 278.54 & 283.83 & 286.20 & 289.70 & 292.04 \\
\hline 0.0025 & 284.16 & 286.58 & 289.99 & 291.96 & 293.67 & 286.35 & 289.16 & 292.24 & 294.99 & 297.67 \\
\hline 0.0030 & 283.89 & 286.64 & 289.58 & 291.34 & 293.26 & 286.29 & 289.45 & 292.02 & 294.63 & 297.58 \\
\hline 0.0034 & 281.49 & 286.03 & 289.58 & 292.12 & 294.22 & 284.04 & 289.01 & 292.15 & 295.56 & 298.73 \\
\hline 0.0040 & 284.55 & 286.47 & 289.83 & 292.10 & 294.53 & 287.30 & 289.67 & 292.59 & 295.78 & 299.35 \\
\hline 0.0080 & 284.65 & 287.45 & 290.44 & 292.97 & 295.40 & 288.50 & 291.88 & 294.17 & 297.92 & 301.89 \\
\hline 0.0100 & 284.71 & 287.44 & 290.25 & 292.83 & 295.27 & 289.01 & 292.36 & 294.38 & 298.31 & 302.45 \\
\hline 0.0130 & 284.95 & 287.77 & 290.69 & 293.40 & 295.88 & 289.84 & 293.35 & 295.35 & 299.56 & 303.95 \\
\hline
\end{tabular}


Table 3 Concentration dependence of apparent molar volumes and partial molar volumes for DTAB in $0.25 \mathrm{~m}$ aqueous glycine solutions at $288.15,296.15,304.15,312.15$, and $320.15 \mathrm{~K}$

\begin{tabular}{|c|c|c|c|c|c|c|c|c|c|c|}
\hline \multirow{2}{*}{$\begin{array}{l}\text { Conc. } \\
\mathrm{m}\left(\mathrm{mol} \mathrm{kg}^{-1}\right)\end{array}$} & \multicolumn{5}{|c|}{ Apparent molar volume $\varphi_{\mathrm{v}}\left(\mathrm{cm}^{3} \mathrm{~mol}^{-1}\right)$} & \multicolumn{5}{|c|}{ Partial molar volume $\overline{V_{2}}\left(\mathrm{~cm}^{3} \mathrm{~mol}^{-1}\right)$} \\
\hline & $288.15 \mathrm{~K}$ & $296.15 \mathrm{~K}$ & $304.15 \mathrm{~K}$ & $312.15 \mathrm{~K}$ & $320.15 \mathrm{~K}$ & $288.15 \mathrm{~K}$ & $296.15 \mathrm{~K}$ & $304.15 \mathrm{~K}$ & $312.15 \mathrm{~K}$ & $320.15 \mathrm{~K}$ \\
\hline 0.0005 & 527.06 & 526.37 & 516.16 & 518.21 & 524.64 & 512.68 & 512.24 & 502.77 & 504.89 & 510.90 \\
\hline 0.0010 & 342.66 & 341.33 & 342.19 & 345.26 & 352.56 & 322.32 & 321.34 & 323.26 & 326.42 & 333.13 \\
\hline 0.0015 & 296.96 & 301.41 & 304.08 & 305.60 & 309.28 & 272.06 & 276.94 & 280.90 & 282.52 & 285.49 \\
\hline 0.0020 & 296.30 & 299.27 & 300.93 & 302.77 & 307.27 & 267.54 & 271.01 & 274.16 & 276.12 & 279.79 \\
\hline 0.0025 & 288.41 & 292.04 & 294.67 & 296.27 & 300.42 & 256.26 & 260.44 & 264.74 & 266.47 & 269.70 \\
\hline 0.0030 & 273.93 & 276.66 & 278.55 & 281.59 & 285.45 & 238.71 & 242.05 & 245.76 & 248.95 & 251.80 \\
\hline 0.0035 & 267.82 & 272.46 & 274.43 & 276.25 & 280.22 & 229.78 & 235.07 & 239.01 & 241.00 & 243.87 \\
\hline 0.0040 & 272.12 & 275.25 & 278.05 & 280.25 & 283.85 & 231.45 & 235.28 & 240.19 & 242.56 & 244.99 \\
\hline 0.0080 & 294.92 & 297.52 & 299.93 & 302.51 & 305.25 & 237.41 & 241.00 & 246.38 & 249.21 & 250.29 \\
\hline 0.0099 & 289.79 & 292.66 & 295.32 & 297.84 & 301.03 & 225.81 & 229.79 & 235.75 & 238.55 & 239.89 \\
\hline 0.0130 & 287.21 & 289.73 & 292.36 & 294.92 & 297.94 & 213.89 & 217.69 & 224.10 & 226.97 & 227.88 \\
\hline
\end{tabular}

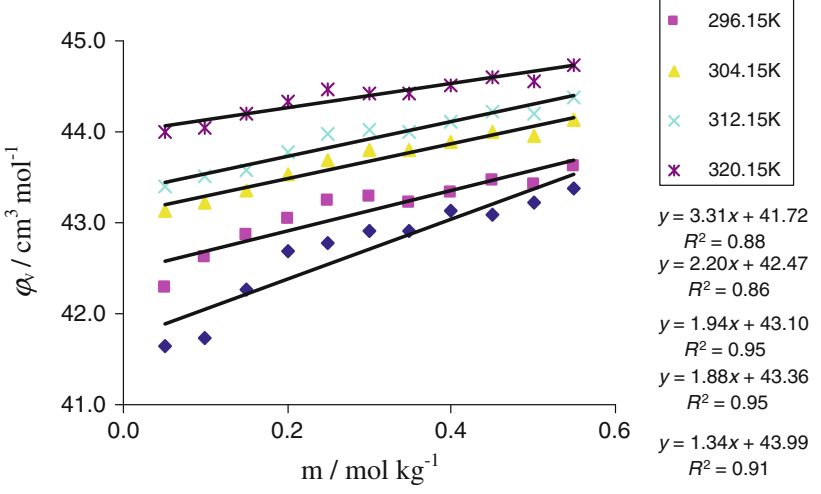

Fig. 1 Plots of apparent molar volume versus molality of glycine in aqueous solutions at different temperatures

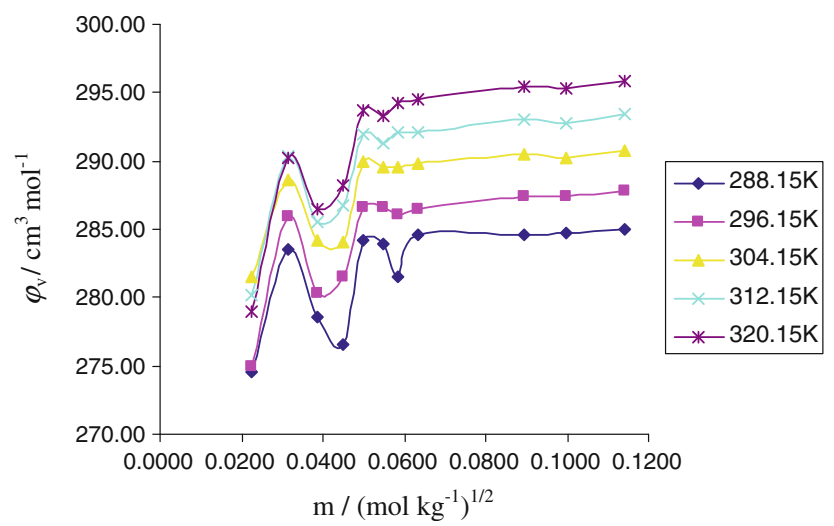

Fig. 2 Apparent molar volume versus (molality) ${ }^{1 / 2}$ of DTAB in aqueous solutions at different temperatures

molecules exist as monomers, and the monomer-monomer interaction may account for $\varphi_{\mathrm{v}}$ with concentration having the free space between the molecules [18].

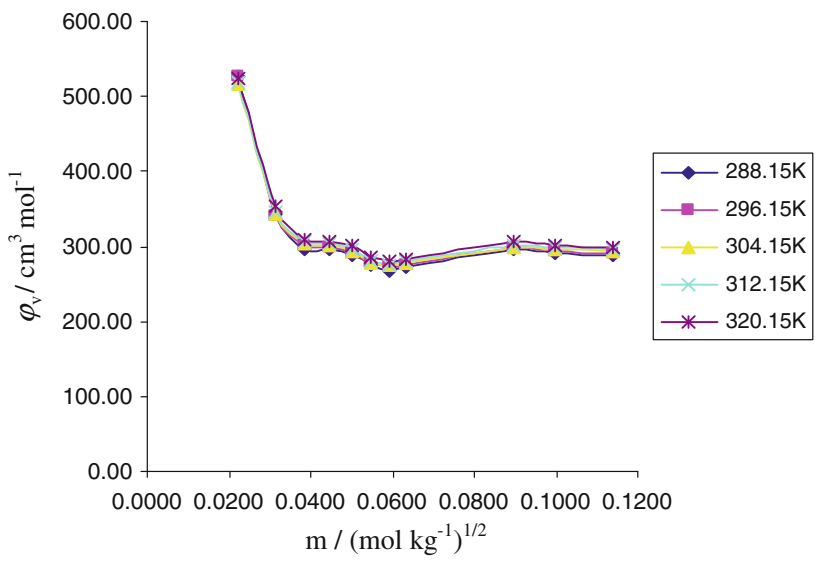

Fig. 3 Apparent molar volume versus (molality) $)^{1 / 2}$ of DTAB in $0.25 \mathrm{~m}$ aqueous glycine solutions at different temperatures

For DTAB, glycine, and alanine in aqueous solutions, the value of $\overline{V_{2}}$ increases with increasing molality and the value of $\overline{V_{1}}$ slightly decreases. This suggests that ion-solvent interactions increase with increasing molality of the solute. On the other hand, DTAB in aqueous amino acid solutions shows the opposite effect.

The apparent molar volume at infinite dilution $\left(\varphi_{\mathrm{v}}^{0}\right)$ was calculated using a least-squares fit to the linear plots of experimental values of $\varphi_{\mathrm{v}}$ versus the square root of molar concentration $(\sqrt{\mathrm{m}})$ using the Masson equation [19]:

$\varphi_{\mathrm{v}}=\varphi_{\mathrm{v}}^{0}+S_{\mathrm{v}} \sqrt{\mathrm{m}}$

where $S_{\mathrm{v}}$ is the experimental slope, which is sometimes considered to be the volumetric pairwise interaction coefficient $[20,21]$. The limiting apparent molar volume $\left(\varphi_{\mathrm{v}}^{0}\right)$ and $S_{\mathrm{v}}$ values along with standard errors are given in Table 4. It is evident from the table that the values of $S_{\mathrm{v}}$ are positive for DTAB in water at different temperatures. Since 
Table 4 Limiting apparent molar volumes $\left(\varphi_{\mathrm{v}}^{0}\right)$ and experimental slopes $\left(S_{\mathrm{v}}\right)$ for binary and ternary solutions at different temperatures

\begin{tabular}{|c|c|c|c|c|}
\hline System & Temperature $(\mathrm{K})$ & $\varphi_{\mathrm{v}}^{0}\left(\mathrm{~cm}^{3} \mathrm{~mol}^{-1}\right)$ & $S_{\mathrm{v}}\left(\mathrm{cm}^{3} \mathrm{dm}^{3 / 2} \mathrm{~mol}^{-1}\right)$ & {$\left[\delta^{2} \varphi_{\mathrm{v}}^{0} / \delta T^{2}\right]_{\mathrm{p}}$} \\
\hline \multirow[t]{5}{*}{ DTAB + water } & 288.15 & $276.93( \pm 5.36 \mathrm{E}-04)$ & $84.52( \pm 2.06 \mathrm{E}-02)$ & \multirow{5}{*}{$-1.2428( \pm 8.57 \mathrm{E}-07)$} \\
\hline & 296.15 & $279.14( \pm 4.79 \mathrm{E}-04$ & $94.55( \pm 1.86 \mathrm{E}-02)$ & \\
\hline & 304.15 & $283.87( \pm 4.32 \mathrm{E}-04)$ & $75.66( \pm 1.67 \mathrm{E}-02)$ & \\
\hline & 312.15 & $284.54( \pm 3.73 \mathrm{E}-04)$ & $99.39( \pm 1.49 \mathrm{E}-02)$ & \\
\hline & 320.15 & $284.41( \pm 3.16 \mathrm{E}-04)$ & $130.02(1.34 \mathrm{E}-02)$ & \\
\hline \multirow[t]{5}{*}{ Glycine + water } & 288.15 & $41.72( \pm 6.99 \mathrm{E}-03)$ & $3.31( \pm 8.19 \mathrm{E}-01)$ & \multirow[t]{5}{*}{$-0.0928( \pm 4.21 \mathrm{E}-04)$} \\
\hline & 296.15 & $42.47( \pm 9.10 \mathrm{E}-03)$ & $2.20( \pm 7.84 \mathrm{E}-01)$ & \\
\hline & 304.15 & $43.10( \pm 8.97 \mathrm{E}-03)$ & $1.93( \pm 7.75 \mathrm{E}-01)$ & \\
\hline & 312.15 & $43.36( \pm 8.92 \mathrm{E}-03)$ & $1.88( \pm 7.75 \mathrm{E}-01)$ & \\
\hline & 320.15 & $43.99( \pm 8.04 \mathrm{E}-03)$ & $1.34( \pm 7.73 \mathrm{E}-01)$ & \\
\hline \multirow[t]{5}{*}{$r a c-\mathrm{Ala}+$ water } & 288.15 & $58.64( \pm 8.06 \mathrm{E}-03)$ & $3.25( \pm 6.00 \mathrm{E}-01)$ & \multirow[t]{5}{*}{$-0.2828( \pm 1.83 \mathrm{E}-04)$} \\
\hline & 296.15 & $59.76( \pm 6.92 \mathrm{E}-03)$ & $2.06( \pm 5.92 \mathrm{E}-01)$ & \\
\hline & 304.15 & $60.54( \pm 6.21 \mathrm{E}-03)$ & $1.32( \pm 5.88 \mathrm{E}-01)$ & \\
\hline & 312.15 & $60.66( \pm 6.62 \mathrm{E}-03)$ & $1.46( \pm 5.89 \mathrm{E}-01)$ & \\
\hline & 320.15 & $61.12( \pm 6.20 \mathrm{E}-03)$ & $1.37( \pm 5.87 \mathrm{E}-01)$ & \\
\hline \multirow[t]{5}{*}{$\mathrm{DTAB}+0.25 \mathrm{~m}$ Gly + water } & 288.15 & $390.52( \pm 7.38 \mathrm{E}-04)$ & $-1,286.07( \pm 1.99 \mathrm{E}-02)$ & \multirow[t]{5}{*}{$2.2186( \pm 5.21 \mathrm{E}-06)$} \\
\hline & 296.15 & $391.67( \pm 6.87 \mathrm{E}-04)$ & $-1,263.80( \pm 1.79 \mathrm{E}-02)$ & \\
\hline & 304.15 & $388.72( \pm 6.16 \mathrm{E}-04)$ & $-1,197.30( \pm 1.60 \mathrm{E}-02)$ & \\
\hline & 312.15 & $390.64( \pm 5.66 \mathrm{E}-04)$ & $-1,191.80( \pm 1.45 \mathrm{E}-02)$ & \\
\hline & 320.15 & $397.12( \pm 5.41 \mathrm{E}-04)$ & $-1,228.90( \pm 1.29 \mathrm{E}-02)$ & \\
\hline \multirow[t]{5}{*}{$\mathrm{DTAB}+0.25 \mathrm{~m} \mathrm{rac}-\mathrm{Ala}+$ water } & 288.15 & $373.92( \pm 7.07 \mathrm{E}-04)$ & $-1,156.60( \pm 2.22 \mathrm{E}-02)$ & \multirow[t]{5}{*}{$0.7872( \pm 2.50 \mathrm{E}-06)$} \\
\hline & 296.15 & $373.94( \pm 6.57 \mathrm{E}-04)$ & $-1,120.80( \pm 2.04 \mathrm{E}-02)$ & \\
\hline & 304.15 & $375.81( \pm 6.03 \mathrm{E}-04)$ & $-1,111.10( \pm 1.85 \mathrm{E}-02)$ & \\
\hline & 312.15 & $374.65( \pm 5.44 \mathrm{E}-04)$ & $-1,066.70( \pm 1.68 \mathrm{E}-02)$ & \\
\hline & 320.15 & $378.94( \pm 5.14 \mathrm{E}-04)$ & $-1,085.80( \pm 1.55 \mathrm{E}-02)$ & \\
\hline
\end{tabular}

$S_{\mathrm{v}}$ is a measure of solute-solute/ion-ion interactions, the result indicates the presence of very strong ion-ion interactions. For DTAB in aqueous amino acid solutions, the values of $S_{\mathrm{v}}$ are negative, which indicates the very weak ion-ion interactions in this region.

The limiting apparent molar volume $\left(\varphi_{\mathrm{v}}^{0}\right)$, which is taken to be the partial molar volume at infinite dilution of DTAB in aqueous and in aqueous amino acid solutions, reflects the true volume of the solute and the volume change arising from solute-solvent interactions. The variation of $\varphi_{\mathrm{v}}^{0}$ with the molality of DTAB can be rationalized in terms of the cosphere overlap model [22].

According to the model, the overlap of the cospheres of two ions or polar groups or an ion with that of a hydrophilic group always produces a positive volume change. On the other hand, the overlap of the cosphere of an ion with that of hydrophobic groups results in a negative volume change. On the overlap of the cospheres of DTAB-DTAB and DTABhydrophilic groups, zwitterionic interactions may take place. The overlap of the cospheres of DTAB gives a positive change in volume due to relaxation of the electrostricted water molecules due to strongly localized ion-zwitterion interactions from the cospheres of amino acid and DTAB, which may cause an increase in volume [23].

The positive volume change due to the overlap of the cospheres of amino acids with those of the hydrophilic groups of DTAB outweighs the negative volume change due to the overlap of cospheres of amino acids and hydrophobic groups of DTAB (negligible), giving a greater $\varphi_{\mathrm{v}}^{0}$ value in amino acid compared with that in water in this region (Table 4$)$. The water-water and water-amino acid interactions are assumed to be the same and do not produce a considerable change in volume. An increase in the molality of DTAB increases the ion-zwitterion and also the DTAB-DTAB interactions, giving rise to increased $\varphi_{\mathrm{v}}^{0}$ values.

The increase of $\varphi_{\mathrm{v}}^{0}$ with temperature may be due to the result of the following effects [24]:

(1) At higher temperature the thermal energy of the water molecules is increased, causing fast movement of the bulk electrostricted water molecules from the interaction region of $\left(\mathrm{CH}_{3}\right)_{3} \mathrm{~N}^{+}-$and $-\mathrm{COOH}$ groups, resulting in a positive volume change. 
(2) An increase in temperature decreases the DTABDTAB interaction, giving rise to a small negative volume change.

(3) A decrease in DTAB-water interactions causes a positive volume change.

(4) The water-water interactions decrease with increasing temperature, giving rise to a small negative change in volume.

In DTAB in aqueous and in aqueous amino acid solutions, the DTAB-DTAB and DTAB-zwitterion interactions increase, giving rise to an increased $\varphi_{\mathrm{v}}^{0}$ value.

The $\varphi_{\mathrm{v}}^{0}$ value of DTAB in ternary solution can alternatively be thought of as arising from four constituents [25]:

$\varphi_{v}^{0}=V_{\mathrm{w}}+V_{\mathrm{f}}+V_{\mathrm{n}}+V_{\mathrm{s}}$,

where $V_{\mathrm{w}}$ and $V_{\mathrm{f}}$ are van der Waals volumes [26] and volume of empty spaces present therein. $V_{\mathrm{n}}$ and $V_{\mathrm{s}}$ represent contributions due to hydrophobic and hydrophilic hydration.

Table 5 Concentration dependence of viscosity for glycine in aqueous solutions at $288.15,296.15,304.15,312.15$, and $320.15 \mathrm{~K}$

\begin{tabular}{|c|c|c|c|c|c|}
\hline \multirow{2}{*}{$\begin{array}{l}\text { Conc. } \\
\mathrm{m}\left(\mathrm{mol} \mathrm{kg}^{-1}\right)\end{array}$} & \multicolumn{5}{|c|}{ Viscosity $\eta(\mathrm{cP})$} \\
\hline & $288.15 \mathrm{~K}$ & $296.15 \mathrm{~K}$ & $304.15 \mathrm{~K}$ & $312.15 \mathrm{~K}$ & $320.15 \mathrm{~K}$ \\
\hline 0.0499 & 1.137880 & 0.942678 & 0.793556 & 0.673591 & 0.580944 \\
\hline 0.1003 & 1.147339 & 0.948971 & 0.797374 & 0.676478 & 0.582315 \\
\hline 0.1501 & 1.150220 & 0.954667 & 0.802681 & 0.683000 & 0.587100 \\
\hline 0.1997 & 1.165109 & 0.960280 & 0.808677 & 0.687347 & 0.591364 \\
\hline 0.2504 & 1.167401 & 0.966909 & 0.813114 & 0.691004 & 0.595743 \\
\hline 0.2998 & 1.172076 & 0.973330 & 0.819991 & 0.701196 & 0.599757 \\
\hline 0.3486 & 1.186965 & 0.979896 & 0.825447 & 0.707964 & 0.608078 \\
\hline 0.3985 & 1.192241 & 0.986627 & 0.829158 & 0.703235 & 0.607041 \\
\hline
\end{tabular}

$V_{\mathrm{w}}$ and $V_{\mathrm{f}}$ are assumed to be the same in aqueous amino acids as in water. The variation of $\varphi_{\mathrm{v}}^{0}$ is therefore due to the change in $\left(V_{\mathrm{n}}+V_{\mathrm{s}}\right)$ resulting from DTAB-amino acid, amino acid-amino acid, and amino acid-water interactions; the contribution from water-water is assumed to be negligible.

The temperature dependence of the limiting apparent molar volume $\varphi_{\mathrm{v}}^{0}$ for binary and ternary solution can be expressed by the expression

$\varphi_{v}^{0}=\mathrm{a}+\mathrm{b} T+\mathrm{c} T^{2}$.

The sign of $\left[\frac{\partial^{2} \varphi_{v}^{0}}{\partial T^{2}}\right]_{p}$, i.e., the second derivative of the limiting apparent molar volume of the solution with respect to temperature at constant pressure, which correspond to structure-making or structure-breaking properties of solution, was determined [27]. For binary and ternary solutions, the values of $\left[\frac{\partial^{2} \varphi_{\mathrm{v}}^{0}}{\partial T^{2}}\right]_{\mathrm{p}}$ are shown in Table 4 . Glycine, alanine, and DTAB in aqueous solutions show negative values of $\left[\frac{\partial^{2} \varphi_{v}^{0}}{\partial T^{2}}\right]_{\mathrm{p}}$, indicating that glycine, alanine, and DTAB act as structure breakers for water solvent systems [28]. Similar information was reported by Devine and Lowe [29]. Again, the value of $\left[\frac{\partial^{2} \varphi_{v}^{0}}{\partial T^{2}}\right]_{p}$ was found to be positive for DTAB in aqueous amino acid solutions, corresponding to structure-making property of water [27].

Viscosity properties of glycine and DTAB in aqueous and DTAB in aqueous amino acid solutions were measured at $288.15,296.15,304.15,312.15$, and $320.15 \mathrm{~K}$. The relevant data are shown in Tables 5 and 6 .

The representative curves (viscosity versus molality) for binary and ternary systems are linear and are shown in

Table 6 Concentration dependence of viscosity for DTAB in aqueous and DTAB in $0.25 \mathrm{~m}$ glycine aqueous solutions at $288.15,296.15$, $304.15,312.15$, and $320.15 \mathrm{~K}$

\begin{tabular}{|c|c|c|c|c|c|c|c|c|c|c|}
\hline \multicolumn{6}{|l|}{ DTAB } & \multicolumn{5}{|c|}{ DTAB $+0.25 \mathrm{~m}$ glycine } \\
\hline \multirow{2}{*}{$\begin{array}{l}\text { Conc. } \\
\mathrm{m}\left(\mathrm{mol} \mathrm{kg}^{-1}\right)\end{array}$} & \multicolumn{5}{|c|}{ Viscosity $\eta(\mathrm{cP})$} & \multicolumn{5}{|c|}{ Viscosity $\eta(\mathrm{cP})$} \\
\hline & $288.15 \mathrm{~K}$ & $296.15 \mathrm{~K}$ & $304.15 \mathrm{~K}$ & $312.15 \mathrm{~K}$ & $320.15 \mathrm{~K}$ & $288.15 \mathrm{~K}$ & $296.15 \mathrm{~K}$ & $304.15 \mathrm{~K}$ & $312.15 \mathrm{~K}$ & $320.15 \mathrm{~K}$ \\
\hline 0.0005 & 1.140515 & 0.942544 & 0.780821 & 0.666754 & 0.578572 & 1.163237 & 0.966766 & 0.818132 & 0.685966 & 0.603104 \\
\hline 0.0010 & 1.137853 & 0.940308 & 0.784959 & 0.664363 & 0.576847 & 1.174014 & 0.972239 & 0.817642 & 0.689824 & 0.598130 \\
\hline 0.0015 & 1.137689 & 0.942212 & 0.787145 & 0.660770 & 0.576553 & 1.169530 & 0.977138 & 0.814032 & 0.688972 & 0.593354 \\
\hline 0.0020 & 1.136180 & 0.957896 & 0.790749 & 0.660949 & 0.574375 & 1.169226 & 0.981347 & 0.820553 & 0.691945 & 0.593703 \\
\hline 0.0025 & 1.135044 & 0.955332 & 0.789985 & 0.658062 & 0.573453 & 1.172392 & 0.976990 & 0.812960 & 0.693833 & 0.594558 \\
\hline 0.0030 & 1.138992 & 0.954772 & 0.797780 & 0.661215 & 0.574824 & 1.180319 & 0.971528 & 0.817157 & 0.688168 & 0.593483 \\
\hline 0.0034 & 1.134168 & 0.945214 & 0.782197 & 0.669451 & 0.582811 & 1.168365 & 0.972365 & 0.814383 & 0.686140 & 0.597807 \\
\hline 0.0040 & 1.137100 & 0.946604 & 0.794392 & 0.663339 & 0.579485 & 1.174915 & 0.970780 & 0.814982 & 0.687410 & 0.583213 \\
\hline 0.0080 & 1.136934 & 0.947222 & 0.780352 & 0.663789 & 0.578529 & 1.174910 & 0.970893 & 0.815146 & 0.682075 & 0.590829 \\
\hline 0.0100 & 1.140350 & 0.951443 & 0.787082 & 0.667042 & 0.579036 & 1.176227 & 0.970982 & 0.821448 & 0.682591 & 0.592583 \\
\hline 0.0130 & 1.144537 & 0.959352 & 0.783562 & 0.662832 & 0.576318 & 1.183795 & 0.972362 & 0.827889 & 0.683742 & 0.594707 \\
\hline
\end{tabular}


Figs. 4, 5, and 6. The values of $\eta$ increase with increase in molality and decrease with temperature. According to the "flickering cluster" [30] models of water, there are large void spaces within the hydrogen-bonded framework of the water structure. The linear increase of $\eta$ with concentration may be interpreted by the fact that the molecules may have penetrated into the void spaces and may have a positive interaction with water.

To calculate the viscosity coefficient $B$, the viscosity data were analyzed in terms of the semi-empirical JonesDole equation [31]. The viscosity coefficient $B$ represents information regarding solute-solvent interaction and shape and size effect on the solvent structure $[32,33]$. The calculated values of the $B$ coefficient are presented in Table 7 . The $B$ coefficient values of the studied electrolyte in aqueous solutions are based on the fact that there exists around an ion a region of modified solvent differing from the bulk in structure and in properties. Gurney's [34] cosphere, Frank and Wens [30] A, B, and C zones, and Nightingale's hydrated radius are recent reflections of this idea. From the above approaches, Kaminsky indicated that the observed viscosity changes result from competition

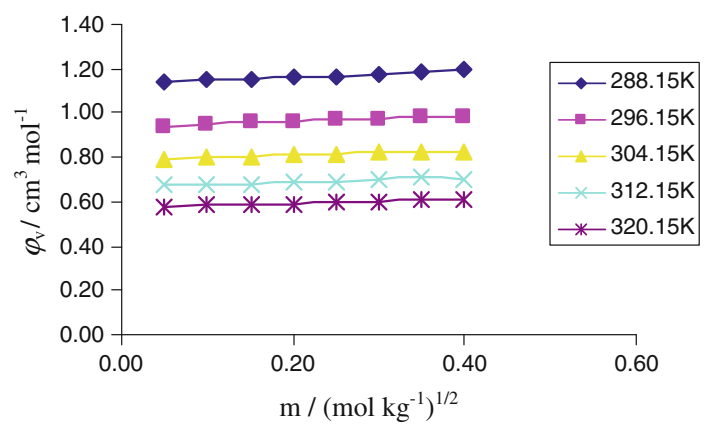

Fig. 4 Viscosity versus molality of glycine in aqueous solutions at different temperatures

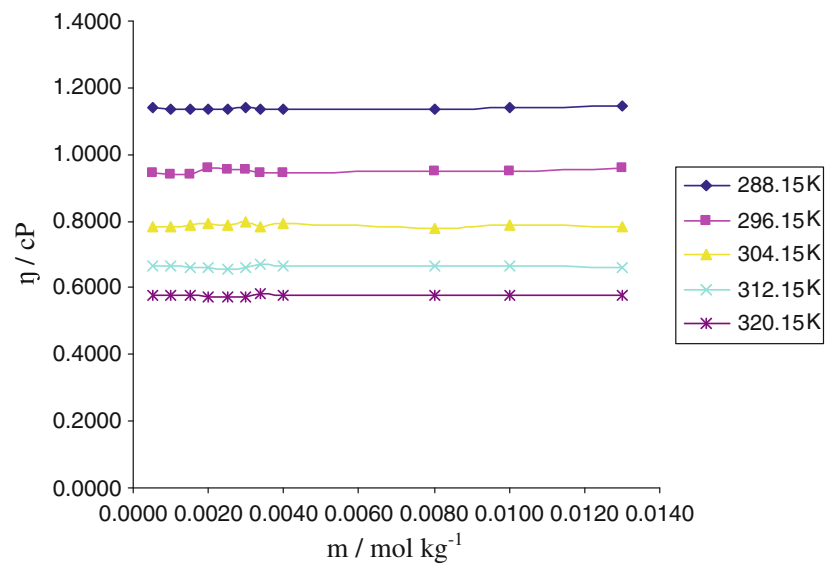

Fig. 5 Viscosity versus molality of DTAB in aqueous solutions at different temperatures

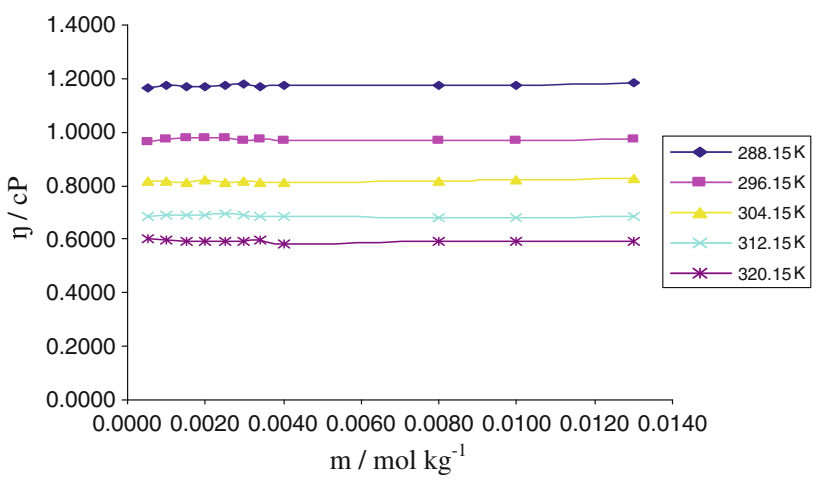

Fig. 6 Viscosity versus molality of DTAB in $0.25 \mathrm{~m}$ aqueous glycine solutions at different temperatures

between various effects occurring in the neighborhood of the ion. The viscosity of a dilute electrolyte solution can be equated to that of the solvent plus the contributions from four other sources in the following manner [35]:

$\eta-\eta_{0}=\Delta \eta^{*}+\Delta \eta^{\mathrm{E}}+\Delta \eta^{\mathrm{A}}+\Delta \eta^{\mathrm{D}}$,

where $\Delta \eta^{*}$ is the positive increment in the viscosity caused by coulombic interactions, and $\Delta \eta^{\mathrm{E}}$ is the viscosity increment arising from the size and shape of an ion, which is closely related to the Einstein effect; it is always positive and normally increases with increasing ion size [36, 37]. $\Delta \eta^{\mathrm{A}}$ is the increment due to the alignment or orientation of polar molecules by the ionic field. Since the freedom of movement of these molecules is restricted, this generally results in a "stiffening" of the solution, and the increment will again be positive. $\Delta \eta^{\mathrm{D}}$ is the viscosity change associated with distortion of the solvent structure leading to greater fluidity. This distortion can be thought of as due to competing forces from the solvent structure in the bulk and from the ionic field and/or the oriented molecules associated with the ion. In mixed solvents, $\Delta \eta^{\mathrm{D}}$ is of considerable magnitude due to significant distortion in the solvent molecules present in the vicinity of the ionic field [38].

Substituting equation (4) into the following Jones-Dole [21] equation one obtains

$\eta-\eta_{0}=\eta_{0}(A \sqrt{C}+B C)$

or

$\Delta \eta^{*}+\Delta \eta^{\mathrm{E}}+\Delta \eta^{\mathrm{A}}+\Delta \eta^{\mathrm{D}}=\eta_{0}(A \sqrt{C}+B C)$.

Eliminating the contributions due to the ionic interaction from both sides we obtain

$\Delta \eta^{\mathrm{E}}+\Delta \eta^{\mathrm{A}}+\Delta \eta^{\mathrm{D}}=\eta_{0} B C$.

Thus, at a given concentration $(C)$, the coefficient $B$ can be interpreted in terms of a competition between these specialized viscosity effects. The charged cations strongly orient with water molecules and in fact are believed to have 
Table 7 The viscosity coefficient values $A / D, B$, and $\left[\frac{\mathrm{dB}}{\mathrm{dT}}\right]$ for binary and ternary solutions as functions of temperature

\begin{tabular}{|c|c|c|c|c|}
\hline & Temperature $(\mathrm{K})$ & $A$ (coefficient) & $B$ (coefficient) & {$[\mathrm{d} B / \mathrm{d} T]$} \\
\hline \multicolumn{5}{|l|}{ System } \\
\hline \multirow[t]{5}{*}{$\mathrm{DTAB}+$ water } & 288.15 & $-0.0894( \pm 1.50 \mathrm{E}-03)$ & $0.7710( \pm 2.84 \mathrm{E}-04)$ & \multirow[t]{5}{*}{$0.3707( \pm 3.44 \mathrm{E}-04)$} \\
\hline & 296.15 & $0.3552( \pm 9.87 \mathrm{E}-04)$ & $-1.5858( \pm 2.47 \mathrm{E}-03)$ & \\
\hline & 304.15 & $0.0898( \pm 4.98 \mathrm{E}-04)$ & $-0.1300( \pm 1.12 \mathrm{E}-03)$ & \\
\hline & 312.15 & $-0.2788( \pm 2.56 \mathrm{E}-03)$ & $2.1265( \pm 9.76 \mathrm{E}-04)$ & \\
\hline & 320.15 & $-0.0804( \pm 1.45 \mathrm{E}-03)$ & $0.7684( \pm 2.86 \mathrm{E}-04)$ & \\
\hline \multirow[t]{5}{*}{ DTAB +0.25 m (aq) Gly } & 288.15 & $-0.2114( \pm 2.07 \mathrm{E}-04)$ & $2.5888( \pm 9.06 \mathrm{E}-06)$ & \multirow[t]{5}{*}{$-0.0093( \pm 3.55 \mathrm{E}-06)$} \\
\hline & 296.15 & $-0.2390( \pm 1.04 \mathrm{E}-04)$ & $2.7845( \pm 6.58 \mathrm{E}-05)$ & \\
\hline & 304.15 & $-0.1010( \pm 6.21 \mathrm{E}-04)$ & $1.7190( \pm 3.42 \mathrm{E}-04)$ & \\
\hline & 312.15 & $-0.5489( \pm 1.06 \mathrm{E}-03)$ & $4.0708( \pm 5.58 \mathrm{E}-04$ & \\
\hline & 320.15 & $-0.2329( \pm 1.27 \mathrm{E}-04)$ & $1.8993( \pm 2.73 \mathrm{E}-04)$ & \\
\hline \multirow[t]{5}{*}{ DTAB $+0.25 \mathrm{~m}(\mathrm{aq})$ Ala } & 288.15 & $-0.2523( \pm 2.08 \mathrm{E}-03)$ & $4.6372( \pm 2.57 \mathrm{E}-04)$ & \multirow[t]{5}{*}{$-0.0196( \pm 3.98 \mathrm{E}-05)$} \\
\hline & 296.15 & $-0.2758( \pm 2.18 \mathrm{E}-03)$ & $5.4044( \pm 3.73 \mathrm{E}-04)$ & \\
\hline & 304.15 & $0.3495( \pm 4.92 \mathrm{E}-04)$ & $-2.9214( \pm 1.74 \mathrm{E}-03)$ & \\
\hline & 312.15 & $0.1195( \pm 4.90 \mathrm{E}-04)$ & $0.3120( \pm 9.21 \mathrm{E}-04)$ & \\
\hline & 320.15 & $0.1739( \pm 2.57 \mathrm{E}-04)$ & $6.4004( \pm 6.26 \mathrm{E}-04)$ & \\
\hline \multicolumn{5}{|l|}{ Compound } \\
\hline \multirow[t]{5}{*}{ Glycine + water } & 288.15 & $0.1191( \pm 1.13 \mathrm{E}-04)$ & $0.0365( \pm 1.59 \mathrm{E}-04)$ & \multirow[t]{5}{*}{$0.0077( \pm 2.16 \mathrm{E}-04)$} \\
\hline & 296.15 & $0.1162( \pm 1.34 \mathrm{E}-04)$ & $0.0401( \pm 7.65 \mathrm{E}-05)$ & \\
\hline & 304.15 & $0.1274( \pm 5.07 \mathrm{E}-05)$ & $0.0192( \pm 5.58 \mathrm{E}-04)$ & \\
\hline & 312.15 & $0.1848( \pm 3.77 \mathrm{E}-04)$ & $-0.0745( \pm 2.72 \mathrm{E}-03)$ & \\
\hline & 320.15 & $0.1235( \pm 7.97 \mathrm{E}-05)$ & $0.0468( \pm 7.78 \mathrm{E}-05)$ & \\
\hline \multirow[t]{5}{*}{ Alanine + water } & 288.15 & $0.0832( \pm 6.04 \mathrm{E}-04)$ & $0.1655( \pm 1.11 \mathrm{E}-03)$ & \multirow[t]{5}{*}{$0.0242( \pm 2.56 \mathrm{E}-04)$} \\
\hline & 296.15 & $0.2526( \pm 2.02 \mathrm{E}-04)$ & $0.0406( \pm 4.82 \mathrm{E}-04)$ & \\
\hline & 304.15 & $0.2391( \pm 1.38 \mathrm{E}-04)$ & $0.0092( \pm 8.83 \mathrm{E}-04)$ & \\
\hline & 312.15 & $0.2906( \pm 3.83 \mathrm{E}-04)$ & $-0.0611( \pm 1.78 \mathrm{E}-03)$ & \\
\hline & 320.15 & $0.1852( \pm 1.19 \mathrm{E}-04)$ & $0.1158( \pm 4.76 \mathrm{E}-04)$ & \\
\hline
\end{tabular}

a primary sheath of firmly attached molecules which moves with them as a kinetic entity [39]. $\Delta \eta^{\mathrm{E}}$ will therefore be large because the ion plus primary sheath can be visualized as a single entity. It is also probable that, at room temperature, water molecules beyond this inner layer are oriented to some extent, giving positive $\Delta \eta^{\mathrm{A}}$. The sum $\Delta \eta^{\mathrm{E}}+\Delta \eta^{\mathrm{A}}$ will not outweigh the decrement due to $\Delta \eta^{\mathrm{D}}$, because it is thought to be small for these ions and the fixed outward-pointing hydrogen atoms fit reasonably well into the tetrahedral water structure. Thus, in this case of ions, $\Delta \eta^{\mathrm{E}}+\Delta \eta^{\mathrm{A}} \gg \Delta \eta^{\mathrm{D}}$, and the $B$ coefficient is large and positive. The sign of $\frac{\mathrm{dB}}{\mathrm{dT}}$, i.e., the first derivative of the viscosity coefficient of $B$ with respect to temperature, which corresponds to structure-making or structurebreaking properties of solutes, was determined [40]. The values of $\frac{\mathrm{dB}}{\mathrm{dT}}$ are presented in Table 7 .

For glycine, alanine, and DTAB in aqueous solutions the values of $\frac{\mathrm{dB}}{\mathrm{dT}}$ are positive, which corresponds to structurebreaking behavior [41]. Although glycine and alanine have high values of $B$, the simplest amino acids are classified as structure breakers $[33,42,43]$. It is seen that $\frac{\mathrm{dB}}{\mathrm{dT}}$ is negative for DTAB in aqueous amino acid solutions, which indicates that DTAB acts as a structure maker in the aqueous amino acid solvent system [44].

The viscosity coefficient $A$ represents the ion-ion interactions coupled with the size and shape effect of the solute and to some extent solute-solvent interactions. In this study, irregular variation in the values of $A$ was found, which may be due to

(1) Incomplete dissociation and ion association of electrolyte in aqueous and in aqueous amino acid solvent, and

(2) The size of ions which differ in degree of hydration or solvation [45].

The decrease of $A$ with rising temperature is probably due to greater thermal agitation and reduction of attractive forces between the ions. The increase in $A$ value can be explained by the interpenetration effect, which brings the ions closer together [46]. It is found that more $A$ coefficient 
values are negative for DTAB in aqueous glycine solutions than in aqueous alanine solutions. This indicates that DTAB has less solute-solute interaction in the aqueous glycine solvent system. On the other hand the viscosity coefficient $D$ also represents the solute-solute interaction, but it is related to nonelectrolyte solutions. In aqueous glycine and alanine solutions, the coefficient $D$ shows negative values at $312.15 \mathrm{~K}$ (Table 7). The negative $D$ contributions indicate that amino acid-amino acid interactions are decreased compared with amino acidwater interactions.

The thermodynamic properties of glycine, alanine, and DTAB in aqueous and DTAB in aqueous amino acid solutions were calculated at the mentioned temperatures using the Nightingale and Benck [47] and Eyring equations [48] and are shown in Tables 8, 9, and 10 . The $\Delta G^{\#}$ value is positive for all the studied systems. The positive free energy of activation for viscous flow can be interpreted with the help of the Furth model [49], which states that the kinetic species involved in forming cavities or holes in the liquid medium are given by the work required in forming the hole against surface tension of the solution. The solutesolvent interaction, interstitial incorporation, and hydrophilic hydration interaction render the binary and ternary aqueous systems more structured. This is reflected in the positive $\Delta G^{\#}$ value.

It is seen that the $\Delta G^{\#}$ value of glycine in aqueous solutions increases very slowly with increasing solute concentration and decreases with increasing temperature (Fig. 7). The slow increase in $\Delta G^{\#}$ for aqueous amino acid solutions indicates that the structure-destroying property is decreased with increasing solute concentration. Similar structure-making results have been reported by other authors as well [32, 50-52]. For aqueous DTAB solutions, overall decrease of $\Delta G^{\#}$ is shown with increasing solute concentrations at all studied temperatures. This indicates that DTAB acts as a structure breaker for the water system (Fig. 9).

Table 8 Concentration dependence of activation parameters for viscous flow of glycine in aqueous solutions at 288.15, 296.15, 304.15, 312.15, and $320.15 \mathrm{~K}$

\begin{tabular}{llllllll}
\hline $\begin{array}{l}\text { Conc. } \\
\mathrm{m}(\mathrm{mol} \mathrm{kg}\end{array}$ & \multicolumn{2}{l}{ Free energy $\Delta G^{\#}\left(\mathrm{~kJ} \mathrm{~mol}^{-1}\right)$} & & \multicolumn{3}{c}{$\Delta S^{\#}\left(\mathrm{~J} \mathrm{~mol}^{-1} \mathrm{~K}^{-1}\right)$} & $\Delta H^{\#}\left(\mathrm{~kJ} \mathrm{~mol}^{-1} \mathrm{~K}^{-1}\right)$ \\
\cline { 2 - 6 } & $288.15 \mathrm{~K}$ & $296.15 \mathrm{~K}$ & $304.15 \mathrm{~K}$ & $312.15 \mathrm{~K}$ & $320.15 \mathrm{~K}$ & & 15.8745 \\
\hline 0.0499 & 9.4346 & 8.9878 & 8.5807 & 8.1951 & 7.8485 & 22.3979 & 16.0085 \\
0.1003 & 9.4573 & 9.0067 & 8.5953 & 8.2083 & 7.8572 & 22.7845 & 15.8621 \\
0.1501 & 9.4662 & 9.0240 & 8.6141 & 8.2343 & 7.8799 & 22.2375 & 15.9671 \\
0.1997 & 9.5000 & 9.0410 & 8.6350 & 8.2526 & 7.9003 & 22.5068 & 1 \\
0.2504 & 9.5075 & 9.0606 & 8.6512 & 8.2685 & 7.9211 & 22.1468 & 15.8746 \\
0.2998 & 9.5199 & 9.0794 & 8.6744 & 8.3065 & 7.9402 & 21.6264 & 15.7401 \\
0.3486 & 9.5528 & 9.0983 & 8.6933 & 8.3324 & 7.9762 & 21.3803 & 15.6934 \\
0.3985 & 9.5664 & 9.1178 & 8.7071 & 8.3195 & 7.9752 & 22.1618 & 15.9377 \\
\hline
\end{tabular}

Table 9 Concentration dependence of activation parameters for viscous flow of DTAB in aqueous solutions at 288.15, 296.15, 304.15, 312.15, and $320.15 \mathrm{~K}$

\begin{tabular}{llllllll}
\hline $\begin{array}{l}\text { Conc. } \\
\mathrm{m}(\mathrm{mol} \mathrm{kg}\end{array}$ & \multicolumn{3}{l}{ Free energy $\Delta G^{\#}\left(\mathrm{~kJ} \mathrm{~mol}^{-1}\right)$} & & \multicolumn{2}{l}{$\Delta S^{\#}\left(\mathrm{~J} \mathrm{~mol}^{-1} \mathrm{~K}^{-1}\right)$} & $\Delta H^{\#}\left(\mathrm{~kJ} \mathrm{~mol}^{-1} \mathrm{~K}^{-1}\right)$ \\
\cline { 2 - 6 } & $288.15 \mathrm{~K}$ & $296.15 \mathrm{~K}$ & $304.15 \mathrm{~K}$ & $312.15 \mathrm{~K}$ & $320.15 \mathrm{~K}$ & & 16.1548 \\
\hline 0.0005 & 9.4424 & 9.2390 & 9.0182 & 8.8527 & 8.7107 & 23.3540 & 16.1750 \\
0.0010 & 9.4371 & 9.2335 & 9.0319 & 8.8437 & 8.7031 & 23.4297 & 16.2524 \\
0.0015 & 9.4371 & 9.2388 & 9.0392 & 8.8300 & 8.7021 & 23.6858 & 16.4466 \\
0.0020 & 9.4342 & 9.2798 & 9.0511 & 8.8311 & 8.6924 & 24.2968 & 16.4754 \\
0.0025 & 9.4322 & 9.2735 & 9.0491 & 8.8201 & 8.6885 & 24.4082 & 16.4415 \\
0.0030 & 9.4408 & 9.2724 & 9.0742 & 8.8328 & 8.6952 & 24.2627 & 15.8934 \\
0.0034 & 9.4309 & 9.2479 & 9.0246 & 8.8652 & 8.7322 & 22.4694 & 16.1475 \\
0.0040 & 9.4375 & 9.2519 & 9.0642 & 8.8419 & 8.7175 & 23.2975 & 16.1833 \\
0.0080 & 9.4397 & 9.2562 & 9.0218 & 8.8465 & 8.7160 & 23.4363 & 16.2148 \\
0.0100 & 9.4481 & 9.2684 & 9.0449 & 8.8606 & 8.7198 & 23.4995 & 16.5165 \\
0.0130 & 9.4588 & 9.2908 & 9.0356 & 8.8463 & 8.7094 & 24.4922 & \\
\hline
\end{tabular}


Table 10 Concentration dependence of activation parameters for viscous flow of DTAB in $0.25 \mathrm{~m}$ glycine aqueous solutions at $288.15,296.15$, $304.15,312.15$, and $320.15 \mathrm{~K}$

\begin{tabular}{|c|c|c|c|c|c|c|c|}
\hline \multirow{2}{*}{$\begin{array}{l}\text { Conc. } \\
\mathrm{m}\left(\mathrm{mol} \mathrm{kg}^{-1}\right)\end{array}$} & \multicolumn{5}{|c|}{ Free energy $\Delta G^{\#}\left(\mathrm{~kJ} \mathrm{~mol}^{-1}\right)$} & \multirow[t]{2}{*}{$\Delta S^{\#}\left(\mathrm{~J} \mathrm{~mol}{ }^{-1} \mathrm{~K}^{-1}\right)$} & \multirow[t]{2}{*}{$\Delta H^{\#}\left(\mathrm{~kJ} \mathrm{~mol}^{-1} \mathrm{~K}^{-1}\right)$} \\
\hline & $288.15 \mathrm{~K}$ & $296.15 \mathrm{~K}$ & $304.15 \mathrm{~K}$ & $312.15 \mathrm{~K}$ & $320.15 \mathrm{~K}$ & & \\
\hline 0.0005 & 9.5362 & 9.3481 & 9.1830 & 8.9732 & 8.8681 & 21.3961 & 15.65952 \\
\hline 0.0010 & 9.5585 & 9.3623 & 9.1817 & 8.9880 & 8.8462 & 22.4744 & 15.99311 \\
\hline 0.0015 & 9.5495 & 9.3749 & 9.1707 & 8.9850 & 8.8251 & 22.9400 & 16.12851 \\
\hline 0.0020 & 9.5492 & 9.3859 & 9.1913 & 8.9966 & 8.8270 & 22.8369 & 16.10609 \\
\hline 0.0025 & 9.5560 & 9.3752 & 9.1680 & 9.0040 & 8.8312 & 22.7247 & 16.06876 \\
\hline 0.0030 & 9.5724 & 9.3616 & 9.1813 & 8.9829 & 8.8266 & 23.3615 & 16.26074 \\
\hline 0.0035 & 9.5482 & 9.3640 & 9.1730 & 8.9755 & 8.8463 & 22.3963 & 15.9635 \\
\hline 0.0040 & 9.5620 & 9.3603 & 9.1752 & 8.9807 & 8.7807 & 24.1954 & 16.50107 \\
\hline 0.0080 & 9.5649 & 9.3636 & 9.1788 & 8.9636 & 8.8186 & 23.6350 & 16.33571 \\
\hline 0.0099 & 9.5687 & 9.3650 & 9.1996 & 8.9669 & 8.8279 & 23.4604 & 16.29143 \\
\hline 0.0130 & 9.5861 & 9.3705 & 9.2215 & 8.9734 & 8.8397 & 23.5893 & 16.34311 \\
\hline
\end{tabular}

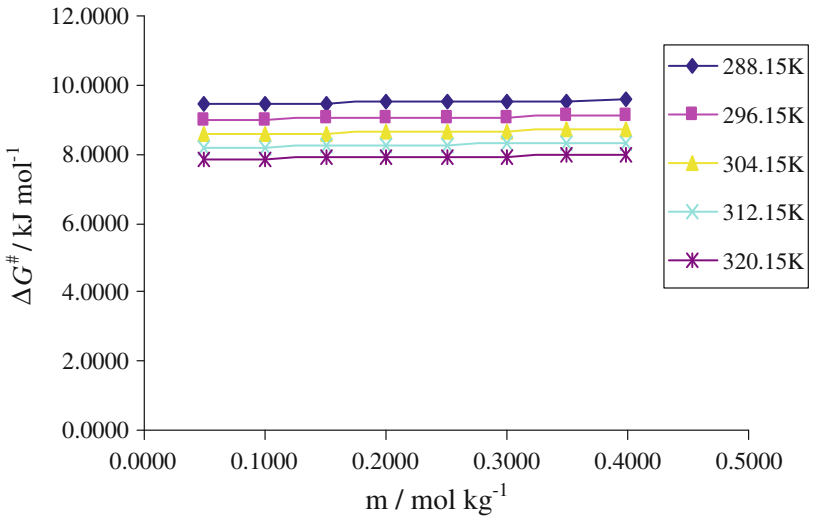

Fig. 7 Free energy of activation versus molality of glycine in aqueous solutions at different temperatures

For DTAB in aqueous glycine solutions, there is an overall increase of $\Delta G^{\#}$ with increasing DTAB concentration (Figs. 8, 9). This indicates that DTAB acts as a structure maker for $\mathrm{H}_{2} \mathrm{O}$-amino acid solvent systems. The change may be attributed to the fact that $\Delta G^{\#}$ controls the rate of flow, which is governed by the slowest step in the fluid process. Similar structure-making results for electrolytes have been reported by other authors earlier [49, 53-55].

The variations of entropy of activation $\left(\Delta S^{\#}\right)$ with the concentration of binary and ternary systems are noted in Tables 8, 9, and 10. The $\Delta S^{\#}$ values for the flow process are positive in all cases but do not follow any specific pattern. It is also found that the values of $\Delta S^{\#}$ for DTAB in the aqueous glycine system are higher than those in the aqueous alanine system, indicating that in the aqueous alanine system the DTAB is more structured than in the aqueous glycine system [51]. This corresponds to the structure-breaking property of solute. The positive values

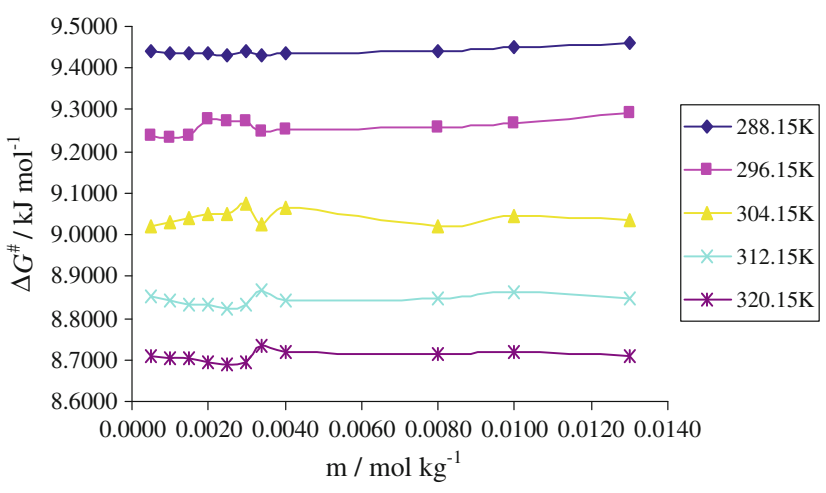

Fig. 8 Free energy of activation versus molality of DTAB in aqueous solutions at different temperatures

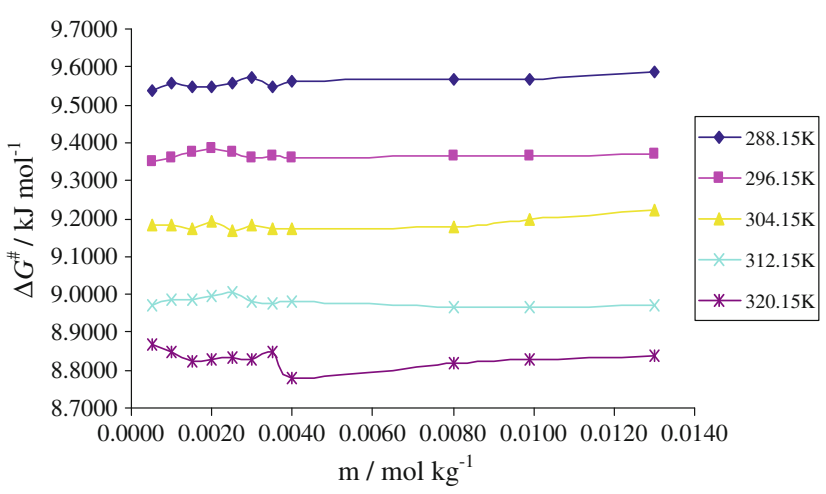

Fig. 9 Free energy of activation versus molality of DTAB in $0.25 \mathrm{~m}$ aqueous glycine solutions at different temperatures

of $\Delta H^{\#}$ indicate that positive work has to be done to overcome the energy barrier for the flow process. That is, viscous flow is not thermodynamically favored for the systems studied. According to Freemantle and Lawrence 
Table 11 Change of chemical potential $\left(\Delta \mu_{1}^{\#}-\Delta \mu_{0}^{\#}\right)$ for glycine in aqueous solutions at 288.15, 296.15, 304.15, 312.15, and 320.15 K

\begin{tabular}{|c|c|c|c|c|c|c|c|c|c|}
\hline \multicolumn{2}{|l|}{$288.15 \mathrm{~K}$} & \multicolumn{2}{|l|}{$296.15 \mathrm{~K}$} & \multicolumn{2}{|l|}{$304.15 \mathrm{~K}$} & \multicolumn{2}{|l|}{$312.15 \mathrm{~K}$} & \multicolumn{2}{|l|}{$320.15 \mathrm{~K}$} \\
\hline Molarity & $\begin{array}{l}\left(\Delta \mu_{1}^{\#}-\Delta \mu_{0}^{\#}\right) \\
\left(\mathrm{kJ} \mathrm{mol}^{-1}\right)\end{array}$ & Molarity & $\begin{array}{l}\left(\Delta \mu_{1}^{\#}-\Delta \mu_{0}^{\#}\right) \\
\left(\mathrm{kJ} \mathrm{mol}^{-1}\right)\end{array}$ & Molarity & $\begin{array}{l}\left(\Delta \mu_{1}^{\#}-\Delta \mu_{0}^{\#}\right) \\
\left(\mathrm{kJ} \mathrm{mol}^{-1}\right)\end{array}$ & Molarity & $\begin{array}{l}\left(\Delta \mu_{1}^{\#}-\Delta \mu_{0}^{\#}\right) \\
\left(\mathrm{kJ} \mathrm{mol}^{-1}\right)\end{array}$ & Molarity & $\begin{array}{l}\left(\Delta \mu_{1}^{\#}-\Delta \mu_{0}^{\#}\right) \\
\left(\mathrm{kJ} \mathrm{mol}^{-1}\right)\end{array}$ \\
\hline 0.0497 & 21.29 & 0.0497 & 21.56 & 0.0496 & 23.77 & 0.0494 & 32.50 & 0.0493 & 33.93 \\
\hline 0.0998 & 21.22 & 0.0996 & 21.54 & 0.0994 & 23.70 & 0.0991 & 32.37 & 0.0988 & 29.09 \\
\hline 0.1490 & 21.21 & 0.1488 & 21.51 & 0.1484 & 23.64 & 0.1480 & 32.22 & 0.1475 & 27.47 \\
\hline 0.1978 & 21.18 & 0.1975 & 21.47 & 0.1971 & 23.59 & 0.1965 & 32.11 & 0.1959 & 26.62 \\
\hline 0.2476 & 21.12 & 0.2471 & 21.43 & 0.2466 & 23.53 & 0.2458 & 31.99 & 0.2450 & 26.09 \\
\hline 0.2958 & 21.06 & 0.2952 & 21.37 & 0.2946 & 23.47 & 0.2937 & 31.85 & 0.2928 & 25.69 \\
\hline 0.3432 & 20.98 & 0.3426 & 21.31 & 0.3418 & 23.40 & 0.3408 & 31.71 & 0.3397 & 25.40 \\
\hline 0.3915 & 20.93 & 0.3908 & 21.26 & 0.3899 & 23.34 & 0.3887 & 31.58 & 0.3875 & 25.17 \\
\hline 0.4410 & 20.85 & 0.4401 & 21.21 & 0.4391 & 23.28 & 0.4378 & 31.46 & 0.4364 & 24.97 \\
\hline 0.4891 & 20.79 & 0.4880 & 21.14 & 0.4868 & 23.20 & 0.4854 & 31.32 & 0.4838 & 24.79 \\
\hline 0.5359 & 20.74 & 0.5347 & 21.11 & 0.5334 & 23.15 & 0.5319 & 31.21 & 0.5301 & 24.66 \\
\hline
\end{tabular}

Table 12 Change of chemical potential $\left(\Delta \mu_{1}^{\#}-\Delta \mu_{0}^{\#}\right)$ for DTAB in aqueous solutions at $288.15,296.15,304.15,312.15$, and $320.15 \mathrm{~K}$

\begin{tabular}{|c|c|c|c|c|c|c|c|c|c|}
\hline \multicolumn{2}{|l|}{$288.15 \mathrm{~K}$} & \multicolumn{2}{|l|}{$296.15 \mathrm{~K}$} & \multicolumn{2}{|l|}{$304.15 \mathrm{~K}$} & \multicolumn{2}{|l|}{$312.15 \mathrm{~K}$} & \multicolumn{2}{|l|}{$320.15 \mathrm{~K}$} \\
\hline Molarity & $\begin{array}{l}\left(\Delta \mu_{1}^{\#}-\Delta \mu_{0}^{\#}\right) \\
\left(\mathrm{kJ} \mathrm{mol}^{-1}\right)\end{array}$ & Molarity & $\begin{array}{l}\left(\Delta \mu_{1}^{\#}-\Delta \mu_{0}^{\#}\right) \\
\left(\mathrm{kJ} \mathrm{mol}^{-1}\right)\end{array}$ & Molarity & $\begin{array}{l}\left(\Delta \mu_{1}^{\#}-\Delta \mu_{0}^{\#}\right) \\
\left(\mathrm{kJ} \mathrm{mol}^{-1}\right)\end{array}$ & Molarity & $\begin{array}{l}\left(\Delta \mu_{1}^{\#}-\Delta \mu_{0}^{\#}\right) \\
\left(\mathrm{kJ} \mathrm{mol}^{-1}\right)\end{array}$ & Molarity & $\begin{array}{l}\left(\Delta \mu_{1}^{\#}-\Delta \mu_{0}^{\#}\right) \\
\left(\mathrm{kJ} \mathrm{mol}^{-1}\right)\end{array}$ \\
\hline 0.0005 & 139.00 & 0.0005 & -178.93 & 0.0005 & 21.19 & 0.0005 & 344.23 & 0.0005 & 153.19 \\
\hline 0.0010 & 140.16 & 0.0010 & -177.48 & 0.0010 & 22.17 & 0.0010 & 345.47 & 0.0010 & 154.80 \\
\hline 0.0015 & 139.46 & 0.0015 & -178.32 & 0.0015 & 21.56 & 0.0015 & 344.59 & 0.0015 & 154.21 \\
\hline 0.0020 & 139.16 & 0.0020 & -178.22 & 0.0020 & 21.54 & 0.0020 & 344.56 & 0.0020 & 154.42 \\
\hline 0.0025 & 140.13 & 0.0025 & -177.58 & 0.0025 & 22.37 & 0.0025 & 345.09 & 0.0025 & 155.19 \\
\hline 0.0030 & 140.06 & 0.0030 & -177.63 & 0.0030 & 22.31 & 0.0030 & 344.81 & 0.0030 & 155.09 \\
\hline 0.0034 & 139.72 & 0.0034 & -177.76 & 0.0034 & 22.31 & 0.0034 & 344.75 & 0.0034 & 155.20 \\
\hline 0.0040 & 140.08 & 0.0040 & -177.77 & 0.0040 & 22.34 & 0.0040 & 344.51 & 0.0040 & 155.19 \\
\hline 0.0080 & 139.81 & 0.0080 & -178.12 & 0.0079 & 22.42 & 0.0079 & 343.02 & 0.0079 & 155.01 \\
\hline 0.0100 & 139.68 & 0.0099 & -178.36 & 0.0099 & 22.39 & 0.0099 & 342.21 & 0.0099 & 154.83 \\
\hline 0.0129 & 139.50 & 0.0129 & -178.67 & 0.0129 & 22.45 & 0.0129 & 341.10 & 0.0128 & 154.69 \\
\hline
\end{tabular}

[32], the viscosity coefficient $B$ is related to the difference in chemical potential for the flow of $1 \mathrm{~mol}$ of solute. The change in chemical potential values $\left(\Delta \mu_{1}^{\#}-\Delta \mu_{0}^{\#}\right)$ indicates the solute-solvent interactions in the solution (shown in Tables 11, 12, 13). A positive and high value of $\left(\Delta \mu_{1}^{\#}-\Delta \mu_{0}^{\#}\right)$ indicates strong interaction between ions and solvents, whereas a low and negative value of $\left(\Delta \mu_{1}^{\#}-\Delta \mu_{0}^{\#}\right)$ indicates structure disorder [53]. Calculated values obtained from the $B$ coefficient data for all systems studied are presented in Table 7. An examination of the data indicates that positive values of $\left(\Delta \mu_{1}^{\#}-\Delta \mu_{0}^{\#}\right)$ are obtained for glycine and alanine in aqueous solutions, corresponding to strong solute-solvent interaction. For DTAB in aqueous solvent systems the values of $\left(\Delta \mu_{1}^{\#}-\right.$ $\left.\Delta \mu_{0}^{\#}\right)$ are negative at $296.15 \mathrm{~K}$, indicating a weak interaction, and positive at $288.15,304.15,312.15$, and
$320.15 \mathrm{~K}$, indicating a strong interaction between ion and solvent. For DTAB in amino acid solvent systems the values of $\left(\Delta \mu_{1}^{\#}-\Delta \mu_{0}^{\#}\right)$ are positive at the studied temperatures, indicating a strong interaction between ion and solvent.

However, for DTAB in the aqueous amino acid solvent system, the values of $\left(\Delta \mu_{1}^{\#}-\Delta \mu_{0}^{\#}\right)$ decrease with increasing DTAB concentration. This indicates that the structuredisordering properties of DTAB increase in the amino acid solvent system.

\section{Conclusions}

The studies on the solution properties of dodecyltrimethylammonium bromide, glycine, and rac-alanine in aqueous 
Table 13 Change of chemical potential $\left(\Delta \mu_{1}^{\#}-\Delta \mu_{0}^{\#}\right)$ for DTAB in $0.25 \mathrm{~m}$ aqueous glycine solutions at 288.15, 296.15, 304.15, 312.15, and $320.15 \mathrm{~K}$

\begin{tabular}{|c|c|c|c|c|c|c|c|c|c|}
\hline \multicolumn{2}{|l|}{$288.15 \mathrm{~K}$} & \multicolumn{2}{|l|}{$296.15 \mathrm{~K}$} & \multicolumn{2}{|l|}{$304.15 \mathrm{~K}$} & \multicolumn{2}{|l|}{$312.15 \mathrm{~K}$} & \multicolumn{2}{|l|}{$320.15 \mathrm{~K}$} \\
\hline Molarity & $\begin{array}{l}\left(\Delta \mu_{1}^{\#}-\Delta \mu_{0}^{\#}\right) \\
\left(\mathrm{kJ} \mathrm{mol}^{-1}\right)\end{array}$ & Molarity & $\begin{array}{l}\left(\Delta \mu_{1}^{\#}-\Delta \mu_{0}^{\#}\right) \\
\left(\mathrm{kJ} \mathrm{mol}^{-1}\right)\end{array}$ & Molarity & $\begin{array}{l}\left(\Delta \mu_{1}^{\#}-\Delta \mu_{0}^{\#}\right) \\
\left(\mathrm{kJ} \mathrm{mol}^{-1}\right)\end{array}$ & Molarity & $\begin{array}{l}\left(\Delta \mu_{1}^{\#}-\Delta \mu_{0}^{\#}\right) \\
\left(\mathrm{kJ} \mathrm{mol}^{-1}\right)\end{array}$ & Molarity & $\begin{array}{l}\left(\Delta \mu_{1}^{\#}-\Delta \mu_{0}^{\#}\right) \\
\left(\mathrm{kJ} \mathrm{mol}^{-1}\right)\end{array}$ \\
\hline 0.0005 & 85.99 & 0.0005 & 68.44 & 0.0005 & 85.70 & 0.0005 & 55.76 & 0.0005 & 58.85 \\
\hline 0.0010 & 61.61 & 0.0010 & 43.35 & 0.0010 & 61.53 & 0.0010 & 31.16 & 0.0010 & 33.83 \\
\hline 0.0015 & 55.57 & 0.0015 & 37.94 & 0.0015 & 56.23 & 0.0015 & 25.52 & 0.0015 & 27.54 \\
\hline 0.0020 & 55.48 & 0.0020 & 37.65 & 0.0020 & 55.79 & 0.0020 & 25.12 & 0.0020 & 27.25 \\
\hline 0.0025 & 54.43 & 0.0025 & 36.66 & 0.0025 & 54.91 & 0.0025 & 24.19 & 0.0025 & 26.25 \\
\hline 0.0030 & 52.51 & 0.0030 & 34.58 & 0.0030 & 52.67 & 0.0030 & 22.11 & 0.0030 & 24.08 \\
\hline 0.0035 & 51.70 & 0.0035 & 34.01 & 0.0035 & 52.09 & 0.0035 & 21.35 & 0.0035 & 23.32 \\
\hline 0.0040 & 52.27 & 0.0040 & 34.38 & 0.0040 & 52.59 & 0.0040 & 21.92 & 0.0040 & 23.84 \\
\hline 0.0080 & 55.23 & 0.0080 & 37.38 & 0.0080 & 55.59 & 0.0080 & 25.07 & 0.0080 & 26.94 \\
\hline 0.0099 & 54.54 & 0.0099 & 36.72 & 0.0099 & 54.93 & 0.0099 & 24.41 & 0.0098 & 26.33 \\
\hline 0.0130 & 54.17 & 0.0130 & 36.31 & 0.0130 & 54.49 & 0.0130 & 23.99 & 0.0129 & 25.87 \\
\hline
\end{tabular}

solution and DTAB in amino acid solutions (glycine/alanine) reveal the following:

(1) DTAB + water: the behavior of DTAB in aqueous solution is temperature dependent. In premicellar region it appears to be a structure breaker for the water solvent system.

(2) Glycine/rac-alanine + water: glycine and rac-alanine in aqueous solutions exhibit similar behavior. Both of the solutes act as structure breakers at all studied temperatures $\left(15-47^{\circ} \mathrm{C}\right)$.

(3) $\mathrm{DTAB}+0.25 \mathrm{~m}$ glycine/rac-alanine: DTAB in aqueous glycine solution acts as a structure maker in premicellar region at all temperatures studied.

\section{Experimental}

The surfactant dodecyltrimethylammonium bromide (DTAB, purity $\geq 98 \%$ ) was purchased from Fluka, Switzerland; the reported critical micellar concentration $(\mathrm{cmc})$ value of DTAB in water is close to $0.015 \mathrm{~m}$ at $25^{\circ} \mathrm{C}$. Glycine (mass fraction $\geq 0.99$ ) and $r a c$-alanine (mass fraction $\geq 0.99$ ) were procured from Fluka chemical company, Switzerland. The chemicals were used without further purification. Supplied distilled water was redistilled and deionized by passing through two ion-exchange columns. The deionized water was distilled again in alkaline $\mathrm{KMnO}_{4}$ medium and was used for preparation of all solutions. Conductivity of this water was found to be $1.00 \mu \mathrm{S}$. The cmc of DTAB in water was determined from conductance measurements. The concentration dependence of molar conductivity of aqueous solutions of DTAB was observed. The molar conductivity decreases with increasing DTAB concentration and shows a sharp break in its value where micelles start to form, determined by extrapolating the molar conductivity data in the premicellar region to intersect with a straight line drawn through the data in the postmicellar region. The estimated $\mathrm{cmc}$ value thus obtained for DTAB is $1.5 \times 10^{-2} \mathrm{~mol} \mathrm{~kg}^{-1}$ at $23^{\circ} \mathrm{C}$, in good agreement with the values reported earlier in literature [52, 56, 57].

An electric balance with accuracy of $\pm 0.0001 \mathrm{~g}$ was used for weighing. Viscosities of various liquids were measured using a calibrated Ostwald-type viscometer. The flow time of liquids was recorded by a timer able to read up to $0.01 \mathrm{~s}$. Temperature was controlled by a water thermostat with accuracy of $\pm 0.1{ }^{\circ} \mathrm{C}$. A densitometer (DSA-5000; Anton Paar, Austria) was used for density measurements.

Acknowledgments The authors gratefully acknowledge the Department of Chemistry, University of Rajshahi, Rajshahi-6205, Bangladesh for providing necessary facilities and help when needed for the work.

Open Access This article is distributed under the terms of the Creative Commons Attribution Noncommercial License which permits any noncommercial use, distribution, and reproduction in any medium, provided the original author(s) and source are credited.

\section{References}

1. Mc Dowali JM, Vincent CA (1974) J Chem Soc Faraday Trans 1862

2. Dack MRJ, Bird KJ, Parker AJ (1975) Aust J Chem 28:955

3. Simpson RB, Kauzamann W (1953) J Am Chem Soc 75:5139

4. Frensdroff HK, Watson MT, Kauzmann W (1953) J Am Chem Soc 75:5157

5. Van Hippel PH, Schleich T (1969) In: Timasheft SN, Fasman GD (eds), Structure and stability of biological macromolecules, vol 2, Dekker, New York, p 417 
6. Motin MA, Biswas TK, Alauddin M, Huque EM (2001) J App Sci Tech 2(1):25

7. Motin MA, Biswas TK, Huque EM (2002) Phys Chem Liq 40:593

8. Afroz S, Motin MA, Biswas TK, Huque EM (2003) Phys Chem Liq 41:249

9. Motin MA, Biswas TK, Huque EM (2003) Monatsh Chem 134:475

10. Dey PC, Motin MA, Biswas TK, Huque EM (2003) Monatsh Chem 134:797

11. Rupley JA (1964) J Phys Chem 68:2003

12. Steinberg IZ, Scheraga HA (1962) J Am Chem Soc 84:2891

13. Negy B, Jencks WP (1965) J Am Chem Soc 87:2480

14. Jencks WP (1969) Catalysis in chemistry and enzymology. McGraw-Hill, New York, p 332

15. Scatchard G, Colman JS, Shen AL (1957) J Am Chem Soc 79:12

16. Singh M, Chand H, Gupta KC (2005) Chem Biodivers 2:809

17. Sreelekhs K, Kund A, Keshore N (2004) J Chem Thermodyn 36:7

18. Gurney RW (1972) Ionic processes in solution: structure, thermodynamics, and transport processes. In: Horne RA (ed). Wiley Interscience, New York

19. Masson DO (1929) Philos Mag 8:218

20. Desnoyers JF (1982) Pure Appl Chem 54:1469

21. Hedwig GR, Reading JF, Lilley TH (1991) J Chem Soc Faraday Trans 87:1951

22. Desnoyers JF, Perron G (1972) J Solution Chem 1:199

23. Millero FJ (1972) Water and aqueous solutions: structure, thermodynamics and transport processes. In: Horne RA (ed). Wiley Interscience, New York

24. Bhat R, Ahluwalia JC (1985) J Phys Chem 89:1099

25. Mishra AK, Ahluwalia JC (1984) J Phys Chem 88:86

26. Bondi A (1959) J Phys Chem 58:929

27. Hepler GL (1969) Can J Chem 47:4613

28. Musbally MG, Perron G, Desnoyers JE (1974) J Colloid Interface Sci 48:494

29. Devine W, Lowe BM (1977) J Chem Soc A 2113

30. Frank HS, Wen WY (1957) Disc Faraday Soc 24:133
31. Jones G, Dole M (1929) J Am Chem Soc 51:2950

32. Feakins D, Freemantle DJ, Lawrence KG (1974) J Chem Soc Faraday Trans 70:795

33. Erdey-Gruz T (1974) Transport phenomena in aqueous solutions, Akad Kiad, Budapest

34. Gurney RW (1953) Ionic processes in solution. McGraw Hill, New York, p 3

35. Stokes RH, Mills R (1965) Viscosity of electrolytes and related properties. Pergamon, London, p 33

36. Einstein A (1906) Ann Phys 19:289

37. Einstein A (1911) Ann Phys 34:591

38. Iqbal MJ, Saleem M, Afzal (1976) Pak J Sci Ind Res 3:21

39. Shoemaker DP, Garland CW, Steinfeld JI, Nibler JW (1981) Experiments in physical chemistry, 4th edn. McGraw-Hill, USA, p 162

40. Glasstone S, Laidler K, Eyring E (1941) The theory of rate process. McGraw-Hill, New York

41. Roy MN, Jha A, Choudhury A (2004) J Chem Eng Data 49:291

42. Tangaries JM, Martin RB (1965) Arch Biochem Biophys 112:267

43. Wadi RW, Goyal RK (1992) J Chem Eng Data 37:377

44. Monimul H, Iqbal AS (2006) J Chem Thermodyn 38:1474

45. Jabeen S, Akber S (1978) Pak J Sci Ind Res 41:299

46. Das BK, Singh KC, Das PK (1976) J Ind Chem Soc 53:112

47. Nightingale ER, Benck RF (1959) J Phys Chem 63:1381

48. Eyring H (1936) J Chem Phys 4:283

49. Furth R (1941) Cambridge Phil Soc 152(276):281

50. Dey NC, Saikia BK, Haque I (1980) Can J Chem 85:1512

51. Islam MN, Wadi RK (1994) J Bangladesh Chem Soc 7:206

52. Benrra Ou M, Bales BL, Zana R (2003) J Phys Chem B 107:13432

53. Huque MM, Rashid MA (1992) J Bangladesh Chem Soc 5:1

54. Murthy NM, Subrahmanyam SV (1980) Can J Chem 58:1527

55. Huque M, Sandulescu (1984) Rev Roum Chim 9:29

56. Alauddin M, Akhter T (1989) MSc Thesis, Department of Chemistry, University of Chittagong

57. Markarian AS, Harutyunyas RL, Harutyunyas SR (2005) J Solution Chem 34:361 